\section{Deep brain stimulation for obsessive compulsive disorder: A review of results by anatomical target}

\author{
Candace Borders, Frank Hsu, \\ Alexander J. Sweidan, Emily S. Matei, \\ Robert G. Bota \\ University of California Irvine, Orange, \\ CA, USA
}

\begin{abstract}
Studies suggest deep brain stimulation (DBS) as a treatment modality for the refractory obsessive-compulsive disorder (OCD). It is unclear where to place the DBS. Various sites are proposed for placement with the ventral capsule/ventral striatum (VC/VS) among the most studied. Herein, we aim to summarize both quantitative Yale-Brown Obsessive-Compulsive Scale (YBOCS) data and qualitative descriptions of the participants' symptoms when given. A literature search conducted via PubMed yielded 32 articles. We sought to apply a standard based on the utilization of YBOCS. This yielded 153 distinct patients. The outcome measure we focused on in this review is the latest YBOCS score reported for each patient/cohort in comparison to the location of the DBS. A total of 32 articles were found in the search results. In total, 153 distinct patients' results were reported in these studies. Across this collection of papers, a total of 9 anatomic structures were targeted. The majority of studies showed a better response at the last time point as compared to the first time point. Most patients had DBS at nucleus accumbens followed by $\mathrm{VC} / \mathrm{VS}$ and the least patients had DBS at the bilateral superolateral branch of the median forebrain bundle and the bilateral basolateral amygdala. The average YBOCS improvement did not seem to directly correlate with the percentile of patients responding to the intervention.

Well-controlled, randomized studies with larger sample sizes with close follow up are needed to provide a more accurate determination for placement of DBS for OCD.
\end{abstract}

\section{Introduction}

OCD is a disabling psychiatric disorder with a lifetime prevalence of $2.3 \%$. OCD patients spend an average of nearly 6 hours per day occupied with intrusive obsessions and performing compulsions or rituals. ${ }^{1}$ Few OCD patients achieve full remission of symptoms. Even in patients receiving a combination of clomipramine, exposure therapy, and ritual prevention therapy, approximately one third do not respond to treatment. 23

Many recent studies suggest stereotactic DBS as a promising treatment modality that may address OCD refractory to current therapies. DBS has been approved by the FDA for treatment of movement disorders; notably, Weaver et. al. demonstrated that DBS led to superior six-month outcomes compared to best medical therapy in advanced Parkinson disease. ${ }^{4}$ DBS remains an investigational treatment for the indication of OCD, but may be used in accordance with a Humanitarian Device Exemption. ${ }^{5}$

Once implanted, the parameters of the electrodes in a DBS device can be adjusted according to a patient's response to treatment. This affords a customizability that makes DBS more likely to be effective in each individual patient. By activating or deactivating specific electrodes in the implanted device, even the location of neuro-stimulation can be slightly adjusted without requiring repeat surgical intervention and re-implantation.

Meta-analysis of the many studies of OCD treatment with DBS remains limited by small sample sizes for each anatomic location, varying psychiatric and medical comorbidities of participants, and the heterogeneous approaches used to report results. ${ }^{6}$ Most of these cases and studies use the Yale-Brown Obsessive-Compulsive Scale (YBOCS) to quantify the severity of patients' symptoms before and after treatment; as such, this is the best metric with which to analyze the compiled results. However, the time points at which these scores are collected vary, and they might be reported for each individual patient or in the aggregate. Moreover, the YBOCS is not sensitive to some changes in symptoms. A decrease in the number of hours spent per day on compulsions from 8 hours to 3 hours would not yield a change in score. Therefore, we aim to summarize per each location both quantitative YBOCS data and qualitative descriptions of the participants' symptoms.

\section{Materials and Methods}

PubMed was used to search for relevant literature using the terms: "obsessive compulsive disorder," "OCD," "deep brain stimulation," "DBS," and "electrical stimulation." Only studies in humans were considered. No patients were eliminated from
Correspondence: Robert G Bota, Department of Psychiatry, University of California Irvine, 101 City Drive

Orange, CA 92617, USA.

Tel.: +1.229.815.0219 - Fax: +1.714.456.2056.

E-mail:rgbota@yahoo.com

Key words: Obsessive compulsive disorder, deep brain stimulation, anatomical target.

Contributions: the authors contributed equally.

Conflict of interest: the authors declare no potential conflict of interest.

Funding: none.

Received for publication: 5 October 2018. Accepted for publication: 5 October 2018.

This work is licensed under a Creative Commons Attribution-NonCommercial 4.0 International License (CC BY-NC 4.0).

(C) Copyright C. Borders et al., 2018

Licensee PAGEPress, Italy

Mental Illness 2018; 10:7900

doi:10.4081/mi.2018.7900

the review on the basis of comorbid psychiatric or medical conditions. Studies not using the YBOCS as an outcome measure were not included. Cohorts of patients whose results were reported in multiple articles were counted once.

In some patients, DBS was not an effective treatment for their OCD symptoms at the first implanted location and the device was surgically removed and re-implanted elsewhere. In these situations, patients were counted as two separate trials. Patients whose devices stimulated two anatomic regions simultaneously were counted once.

Patients for whom an individual posttreatment YBOCS score was given were combined to give an overall mean reduction in YBOCS score. In order to include studies which only reported the number of patients responding to treatment (with a response being a reduction in YBOCS of $35 \%$ or more), rather than a degree of response for each individual, the percentage responders were also calculated where applicable. This threshold for determination of responders versus non-responders was the most commonly used in the literature, and is therefore used here; however, we aim to identify and qualitatively discuss non-responders with clinically relevant improvements in their symptoms of OCD.

Follow-up times among these studies varied from one month to nine years, with some patients being re-tested on the YBOCS very frequently and some only once. Therefore, the outcome measure we 


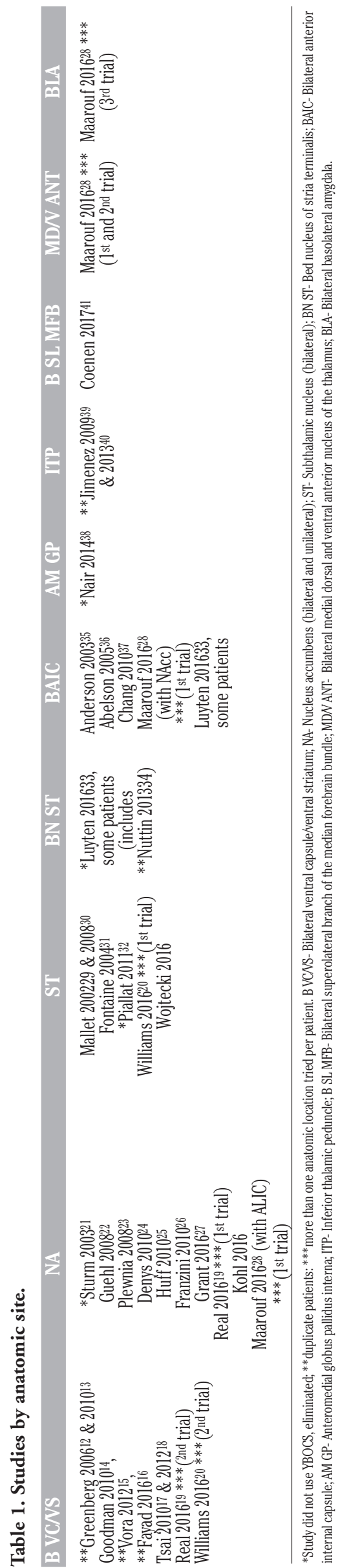

focus on in this review is the latest YBOCS score reported for each patient/cohort. The latest time point was not used if a significant number of patients dropped out of the study before that point. YBOCS score at earliest post-op time point tested was included when given.

\section{Results}

A total of 32 articles were found in the search results. Four were eliminated from consideration due to the absence of YBOCS scores. Three papers reported on the same cohort of six patients; two papers used data

Table 2. Ventral capsule/ventral striatum.

\begin{tabular}{|c|c|c|c|c|c|}
\hline Study & N. & $\begin{array}{l}\text { Average YBOCS } \\
\text { reduction at first } \\
\text { time point }\end{array}$ & $\begin{array}{l}\text { Responders } \\
\text { at first } \\
\text { time point }\end{array}$ & $\begin{array}{c}\text { Average YBOCS } \\
\text { reduction at latest } \\
\text { time point }\end{array}$ & $\begin{array}{l}\text { Responders } \\
\text { at last } \\
\text { time point }\end{array}$ \\
\hline $\begin{array}{l}\text { Greenberg } 2006{ }^{12} \\
\text { and } 2010^{13}\end{array}$ & 26 & $\begin{array}{l}\text { not given } \\
\text { at } 1 \text { month }\end{array}$ & $7 / 25$ & $38 \%$ at $>3$ months & $16 / 26$ \\
\hline Tsai $2010^{17}$ and 201218 & 4 & $n / a$ & $n / a$ & $35 \%$ at $x$ months & $2 / 4$ \\
\hline $\begin{array}{l}\text { Goodmann }{ }^{14} \\
\text { Vora }^{15}, \text { Fayad }^{16}\end{array}$ & 6 & 12 months & $4 / 6$ & 6-9 years & $4 / 6$ \\
\hline Real, trial 219 & 1 & $32 \%$ at 16 wks & $0 / 1$ & $42 \%$ at $1 \mathrm{yr}$ & $1 / 1$ \\
\hline Williams ${ }^{20}$, trial 2 & 1 & $n / a$ & $n / a$ & $69 \%$ at 9 months & $1 / 1$ \\
\hline
\end{tabular}

Table 3. Nucleus accumbens.

\begin{tabular}{|c|c|c|c|c|c|}
\hline Study & N. & $\begin{array}{l}\text { Average YBOCS } \\
\text { reduction at first } \\
\text { time point }\end{array}$ & $\begin{array}{l}\text { Responders } \\
\text { at first } \\
\text { time point }\end{array}$ & $\begin{array}{l}\text { Average YBOCS } \\
\text { reduction at latest } \\
\text { time point }\end{array}$ & $\begin{array}{l}\text { Responders } \\
\text { at last } \\
\text { time point }\end{array}$ \\
\hline Guehl, bilateral22 & 3 & not given & $\mathrm{n} / \mathrm{a}$ & $35-60 \%$ at one year. No average given & en $3 / 3$ \\
\hline Plewnia, unilatera|23 & 1 & $25 \%$ at 4 wks & $0 / 1$ & $21.9 \%$ at 2 years & $0 / 1$ \\
\hline Denys, bilateral24 & 16 & $46 \%$ at 32 weeks, open & $9 / 16$ & $52 \%$ at 21 months & $? / 14$ \\
\hline Huff, unilateral25 & 10 & not given & $\mathrm{n} / \mathrm{a}$ & $21 \%$ at 1 year & $1 / 10$ \\
\hline Franzini, bilateral26 & 2 & not given & $n / a$ & $38 \%$ at $24-27$ months & $2 / 2$ \\
\hline Grant, bilateral27 & 1 & $69 \%$ at 8 months & $1 / 1$ & $69-75 \%$ at 3 years & $1 / 1$ \\
\hline Real, bilateral, trial $1^{19}$ & & not given & $n / a$ & $7.9 \%$ at 2 years & $0 / 1$ \\
\hline $\begin{array}{l}\text { Maarouf28, bilateral, } \\
\text { patient } 3 \text {, trial } 1\end{array}$ & 1 & not given & $n / a$ & not given & $0 / 1$ \\
\hline Kohl, bilateral & 18 & not given & $4 / 18$ & not given & $6 / 12$ \\
\hline
\end{tabular}

Table 4. Anterior limb of the internal capsule.

\begin{tabular}{|c|c|c|c|c|c|}
\hline Study & N. & $\begin{array}{l}\text { Average YBOCS } \\
\text { reduction at first } \\
\text { time point }\end{array}$ & $\begin{array}{l}\text { Responders } \\
\text { at first } \\
\text { time point }\end{array}$ & $\begin{array}{c}\text { Average YBOCS } \\
\text { reduction at latest } \\
\text { time point }\end{array}$ & $\begin{array}{l}\text { Responders } \\
\text { at last } \\
\text { time point }\end{array}$ \\
\hline Anderson 35 & 1 & $79.4 \%$ & $1 / 1$ & $97.1 \%$ & $1 / 1$ \\
\hline Abelson ${ }^{36}$ & 4 & 20.0\% (double blind) & 1/4 (double blind) & $30.25 \%$ (open) & 2/4 (open) \\
\hline Chang37 & 1 & $0 \%$ & $0 / 1$ & $11.1 \%$ & $0 / 1$ \\
\hline Luyten ${ }^{33}$, bilateral & 4 & not given & n/a & $20 \%$ at $>4$ years & $0 / 4$ \\
\hline $\begin{array}{l}\text { Luyten }^{33} \text {, bilateral, } \\
\text { adjacent to NAcc }\end{array}$ & 2 & not given & $n / a$ & $26 \%$ at $>4$ years & $1 / 2$ \\
\hline $\begin{array}{l}\text { Luyten }{ }^{33} \text {, bilateral, } \\
\text { adjacent to BST }\end{array}$ & 1 & not given & $n / a$ & $76 \%$ at $>4$ years & $1 / 1$ \\
\hline $\begin{array}{l}\text { Luyten }^{33} \text {, bilateral } \\
\text { ALIC, left adjacent to } \\
\text { BST and right in BST }\end{array}$ & 1 & not given & $\mathrm{n} / \mathrm{a}$ & $57 \%$ at $>4$ years & $1 / 1$ \\
\hline $\begin{array}{l}\text { Luyten }{ }^{33} \text {, right in } \\
\text { ALIC, left in BST }\end{array}$ & 1 & not given & $n / a$ & $67 \%$ at $>4$ years & $1 / 1$ \\
\hline $\begin{array}{l}\text { Maarouf } 28 \text {, patients } \\
1 \text { and } 2 \text { (with NAcc), } \\
\text { trial } 1\end{array}$ & 2 & not given & $\mathrm{n} / \mathrm{a}$ & not given & $0 / 2$ \\
\hline
\end{tabular}


from the same cohort of eight, and; another two reported on the same five patients. One additional paper was a case study of a patient included in another cohort. In total, 153 distinct patients' results were reported in these studies. Across this collection of papers, a total of nine anatomic structures were targeted (Table 1). Patients in whom the device was re-implanted in a different location had each of their trials counted separately. There was a total of 158 trials for these 153 patients.

The majority of studies showed a better response at the last time point as compared to the first time point (Tables 2-7).7-41

Most patients had DBS at nucleus accumbens followed by VC/VS and the least patients had DBS at the bilateral superolateral branch of the median forebrain bundle and the bilateral basolateral amygdala (Table 8). The average YBOCS improvement did not seem to directly correlate with the percentile of patients responding to the intervention.

\section{Discussion}

The average YBOCS reduction and percent of participants responding to therapy did not follow the same trend. This may be due to a significant difference in response in the sample despite similar intervention. But we also must consider that patients with clinical benefit who did not always meet the "responder" threshold.

Studies with fewer than 4 participants were generally more likely to have positive findings, likely due to publishing bias; we are able to see results of negative case studies in situations where stimulators were eventually re-implanted in a location that produced better results.

The question remains the same, what is the best location to implant the device? Several anatomic locations have been targeted in DBS for the indication of OCD. The VC/VS is among the most studied, followed by the nucleus accumbens. ${ }^{7-9}$ Data is amassing for these few aforementioned locations and fortunately, new locations are being explored with both positive and negative results. Less-studied locations include the subthalamic nucleus, inferior thalamic peduncle, anterior limb of the internal capsule, anteromedial globus pallidus, superolateral branch of the median forebrain bundle, medial dorsal and ventral anterior nucleus of the thalamus, and bed nucleus of the stria terminalis. 1011

Furthermore, the studies that measured YBOCS score at multiple time points demonstrate that response to stimulation does not all occur at the beginning of thera-
Table 5. Subthalamic nucleus.

\begin{tabular}{|c|c|c|c|c|c|}
\hline Study & N. & $\begin{array}{l}\text { Average YBOCS } \\
\text { reduction at first } \\
\text { time point }\end{array}$ & $\begin{array}{l}\text { Responders } \\
\text { at first } \\
\text { time point }\end{array}$ & $\begin{array}{l}\text { Average YBOCS } \\
\text { reduction at latest } \\
\text { time point }\end{array}$ & $\begin{array}{l}\text { Responders } \\
\text { at last } \\
\text { time point }\end{array}$ \\
\hline Mallet et al. 200229 & 2 & $\begin{array}{l}81.6 \% \text { at } 2 \text { weeks or } \\
1-6 \text { month, can't tell } \\
\text { from table }\end{array}$ & $2 / 2$ & $\mathrm{n} / \mathrm{a}$ & $n / a$ \\
\hline Mallet et al. $2008^{30}$ & 16 & $\begin{array}{c}32.1 \% \text { compared to sham } \\
\text { stimulation, } 40.6 \% \text { compared } \\
\text { to baseline }\end{array}$ & $\begin{array}{c}\text { not given, } \\
\text { but guessing } \\
\text { from graph, 10/16 }\end{array}$ & $\mathrm{n} / \mathrm{a}$ & $n / a$ \\
\hline Fontaine et al. 200431 & 1 & $96.9 \%$ at 1 year & $1 / 1$ & $\mathrm{n} / \mathrm{a}$ & $n / a$ \\
\hline Williams, trial 120 & 1 & & & & \\
\hline Wojtecki & 1 & $92.3 \%$ at 3 years & $1 / 1$ & $\mathrm{n} / \mathrm{a}$ & $n / a$ \\
\hline
\end{tabular}

Table 6. Bilateral medial dorsal and ventral anterior nucleus of the thalamus; bilateral superolateral branch of the median forebrain bundle; inferior thalamic peduncle; bilateral basolateral amygdala.

$\begin{array}{ccc}\text { Study } & \text { Average YBOCS } & \text { Responders Average YBOCS Responders } \\ \text { reduction at first } & \text { at first reduction at latest at last } \\ \text { time point } & \text { time point } & \text { time point time point }\end{array}$
$\begin{array}{llll}\text { Maarouf } 28, & 4 & 0 / 4 & \text { not given }\end{array}$ pts 1-3 trial 2 ,

pt 4 trial 1

\begin{tabular}{|c|c|c|c|c|c|}
\hline \multicolumn{6}{|c|}{ Bilateral superolateral branch of the median forebrain bundle } \\
\hline Coenen ${ }^{41}$ & 2 & $31.5 \%$ at 1 month & $1 / 2$ & $41.7 \%$ at 12 months & $1 / 2$ \\
\hline \multicolumn{6}{|c|}{ Inferior thalamic peduncle } \\
\hline Jimenez $2013^{40}$ & 6 & $8.4 \%$ at 1 month & $0 / 6$ & $49 \%$ at 12 months & $6 / 6$ \\
\hline \multicolumn{6}{|c|}{ Bilateral basolateral amygdala } \\
\hline $\begin{array}{l}\text { Maarouf } 28, \\
\text { patient } 3,3 \text { rd tria }\end{array}$ & 1 & not given & $\mathrm{n} / \mathrm{a}$ & not given & $0 / 1$ \\
\hline
\end{tabular}

Table 7. Bed nucleus of stria terminalis (BST).

\begin{tabular}{|c|c|c|c|c|c|}
\hline Study & N. & $\begin{array}{l}\text { Average YBOCS } \\
\text { reduction at first } \\
\text { time point }\end{array}$ & $\begin{array}{l}\text { Responders } \\
\text { at first } \\
\text { time point }\end{array}$ & $\begin{array}{l}\text { Average YBOCS } \\
\text { reduction at latest } \\
\text { time point }\end{array}$ & $\begin{array}{l}\text { Responders } \\
\text { at last } \\
\text { time point }\end{array}$ \\
\hline \multicolumn{6}{|c|}{ Bilateral medial dorsal and ventral anterior nucleus of the thalamus } \\
\hline $\begin{array}{l}\text { Luyten }{ }^{33} \text {, } \\
\text { bilateral }\end{array}$ & 9 & not given & $\mathrm{n} / \mathrm{a}$ & $42 \%$ at $>4$ years & $6 / 9$ \\
\hline $\begin{array}{l}\text { Luyten } 33 \text {, } \\
\text { unilateral right }\end{array}$ & 1 & not given & $\mathrm{n} / \mathrm{a}$ & $77 \%$ at $>4$ years & $1 / 1$ \\
\hline Luyten 33 & 2 & not given & $n / a$ & $51 \%$ at $>4$ years & $2 / 2$ \\
\hline
\end{tabular}

left in BST,

right in IC adjacent

to BST

\begin{tabular}{|c|c|c|c|c|}
\hline $\begin{array}{l}\text { Luyten }^{33}, \\
\text { right in BST, } \\
\text { left in IC adjacent } \\
\text { to BST }\end{array}$ & not given & $\mathrm{n} / \mathrm{a}$ & $58 \%$ at $>4$ years & $1 / 1$ \\
\hline $\begin{array}{l}\text { Luyten }^{33} \text {, bilateral } 1 \\
\text { in prereticular } \\
\text { zone, BST adjacent }\end{array}$ & not given & $\mathrm{n} / \mathrm{a}$ & $35 \%$ at $>4$ years & $1 / 1$ \\
\hline $\begin{array}{l}\text { Luyten }^{33} \text {, bilateral } \\
\text { in IC, BST adjacent }\end{array}$ & not given & $\mathrm{n} / \mathrm{a}$ & $95 \%$ at $>4$ years & $1 / 1$ \\
\hline
\end{tabular}


Table 8. Response per location.

\begin{tabular}{|c|c|c|c|c|c|}
\hline Location & N. & $\begin{array}{l}\text { Average YBOCS } \\
\text { reduction at first } \\
\text { time point }\end{array}$ & $\begin{array}{l}\text { Responders } \\
\text { at first } \\
\text { time point }\end{array}$ & $\begin{array}{l}\text { Average YBOCS } \\
\text { reduction at latest } \\
\text { time point }\end{array}$ & $\begin{array}{l}\text { Responders } \\
\text { at last } \\
\text { time point }\end{array}$ \\
\hline VCNS & 38 & $32 \%$ & $11 / 32$ & $35-69 \%$ & $24 / 38$ \\
\hline Nucleus Accumbens & 53 & 25 to $69 \%$ & $14 / 36$ & 7.9 to $75 \%$ & $13 / 31$ \\
\hline $\begin{array}{l}\text { Anterior limb of the } \\
\text { internal capsule }\end{array}$ & 14 & 20 to $79 \%$ & $2 / 6$ & 11 to $97 \%$ & $7 / 17$ \\
\hline Subthalamic nucleus & 21 & 32 to $96 \%$ & $14 / 20$ & $\mathrm{n} / \mathrm{a}$ & $\mathrm{n} / \mathrm{a}$ \\
\hline $\begin{array}{l}\text { Bilateral medial } \\
\text { dorsal and ventral } \\
\text { anterior nucleus } \\
\text { of the thalamus }\end{array}$ & 4 & not given & $0 / 4$ & Not given & $0 / 4$ \\
\hline $\begin{array}{l}\text { Bilateral superolateral } \\
\text { branch of the median } \\
\text { forebrain bundle }\end{array}$ & 2 & $31 \%$ & $1 / 2$ & $41 \%$ & $1 / 2$ \\
\hline $\begin{array}{l}\text { Inferior thalamic } \\
\text { peduncle }\end{array}$ & 6 & $8 \%$ & $0 / 6$ & $49 \%$ & $6 / 6$ \\
\hline $\begin{array}{l}\text { Bilateral basolateral } \\
\text { amygdala }\end{array}$ & 1 & Not given & $\mathrm{n} / \mathrm{a}$ & Not given & $0 / 1$ \\
\hline $\begin{array}{l}\text { Bed nucleus of stria } \\
\text { terminalis }\end{array}$ & 15 & Not given & $\mathrm{n} / \mathrm{a}$ & 35 to $95 \%$ & $12 / 15$ \\
\hline
\end{tabular}

py; rather, there is an accumulation of the effect. The percent YBOCS increase and the number of patients responding within a study tend to increase with time. In studies where the average YBOCS score did not continue to increase with time, patients still experienced clinical benefit.

\section{Conclusions}

Well-controlled, randomized studies with larger sample sizes with close follow up are needed to provide a more accurate determination for placement of DBS for OCD.

\section{References}

1. Ruscio AM, Stein DJ, Chiu WT, et al. The epidemiology of obsessive-compulsive disorder in the National Comorbidity Survey Replication. Mol Psychiatry 2010;15:53-63.

2. Eisen JL, Pinto A, Mancebo MC, et al. A 2-year prospective follow-up study of the course of obsessive-compulsive disorder. J Clin Psychiatry 2010;71:10339.

3. Simpson HB, Huppert JD, Petkova E, et al. Response versus remission in obsessive-compulsive disorder. J Clin Psychiatry 2006;67:269-76.

4. Weaver FM, Follett K, Stern M, et al. Bilateral deep brain stimulation vs best medical therapy for patients with advanced Parkinson disease: a randomized controlled trial. JAMA
2009;301:63-73.

5. Health NIoM. Brain Stimulation Therapies. Available from: https://wwwnimhnihgov/health/topics/b rain-stimulation-therapies/brain-stimulation-therapiesshtml.

6. Alonso P, Cuadras D, Gabriels L, et al. Deep Brain Stimulation for ObsessiveCompulsive Disorder: A Meta-Analysis of Treatment Outcome and Predictors of Response. PLoS One 2015;10: e0133591.

7. Islam L, Franzini A, Messina G, et al. Deep brain stimulation of the nucleus accumbens and bed nucleus of stria terminalis for obsessive-compulsive disorder: a case series. World Neurosurg 2015;83:657-63.

8. Makris N, Rathi Y, Mouradian P, et al. Variability and anatomical specificity of the orbitofrontothalamic fibers of passage in the ventral capsule/ventral striatum (VC/VS): precision care for patient-specific tractography-guided targeting of deep brain stimulation (DBS) in obsessive compulsive disorder (OCD). Brain Imaging Behav 2016;10:1054-67.

9. Schippers MC, Bruinsma B, Gaastra M, et al. Deep Brain Stimulation of the Nucleus Accumbens Core Affects Trait Impulsivity in a Baseline-Dependent Manner. Front Behav Neurosci 2017;11:52.

10. Chabardes S, Polosan M, Krack P, et al. Deep brain stimulation for obsessivecompulsive disorder: subthalamic nucleus target. World Neurosurg 2013;80:e1-8.
11. Mulders AEP, Plantinga BR, Schruers $\mathrm{K}$, et al. Deep brain stimulation of the subthalamic nucleus in obsessive-compulsive disorder: Neuroanatomical and pathophysiological considerations. Eur Neuropsychopharmacol 2016;26:190919.

12. Greenberg BD, Malone DA, Friehs GM, et al. Three-year outcomes in deep brain stimulation for highly resistant obsessive-compulsive disorder. N europs y chophar m a c olog y 2006;31:2384-93.

13. Greenberg BD, Gabriels LA, Malone DA Jr., et al. Deep brain stimulation of the ventral internal capsule/ventral striatum for obsessive-compulsive disorder: worldwide experience. Mol Psychiatry 2010;15:64-79.

14. Goodman WK, Foote KD, Greenberg $\mathrm{BD}$, et al. Deep brain stimulation for intractable obsessive compulsive disorder: pilot study using a blinded, staggered-onset design. Biol Psychiatry 2010;67:535-42.

15. Vora $\mathrm{AK}$, Ward $\mathrm{H}$, Foote $\mathrm{KD}$, et al. Rebound symptoms following battery depletion in the NIH OCD DBS cohort: clinical and reimbursement issues. Brain Stimul 2012;5:599-604.

16. Fayad SM, Guzick AG, Reid AM, et al. Six-Nine Year Follow-Up of Deep Brain Stimulation for ObsessiveCompulsive Disorder. PLoS One 2016;11:e0167875.

17. Tsai HC, Chen SY, Tsai ST, et al. Hypomania following bilateral ventral capsule stimulation in a patient with refractory obsessive-compulsive disorder. Biol Psychiatry 2010;68:e7-8.

18. Tsai HC, Chang CH, Pan JI, et al. Pilot study of deep brain stimulation in refractory obsessive-compulsive disorder ethnic Chinese patients. Psychiatry Clin Neurosci 2012;66:303-12.

19. Real E, Plans G, Alonso P, et al. Removing and reimplanting deep brain stimulation therapy devices in resistant OCD (when the patient does not respond): case report. BMC Psychiatry 2016;16:26.

20. Williams NR, Hopkins TR, Short EB, et al. Reward circuit DBS improves Parkinson's gait along with severe depression and OCD. Neurocase 2016;22:201-4.

21. Sturm V, Lenartz D, Koulousakis A, et al. The nucleus accumbens: a target for deep brain stimulation in obsessivecompulsive- and anxiety-disorders. J Chem Neuroanat 2003;26:293-9.

22. Guehl D, Benazzouz A, Aouizerate B, et al. Neuronal correlates of obsessions in the caudate nucleus. Biol Psychiatry 
2008;63:557-62.

23. Plewnia C, Schober F, Rilk A, et al. Sustained improvement of obsessivecompulsive disorder by deep brain stimulation in a woman with residual schizophrenia. Int J Neuropsychopharmacol 2008;11:1181-3.

24. Denys D, Mantione M, Figee M, et al. Deep brain stimulation of the nucleus accumbens for treatment-refractory obsessive-compulsive disorder. Arch Gen Psychiatry 2010;67:1061-8.

25. Huff W, Lenartz D, Schormann M, et al. Unilateral deep brain stimulation of the nucleus accumbens in patients with treatment-resistant obsessive-compulsive disorder: Outcomes after one year. Clin Neurol Neurosurg 2010;112:13743.

26. Franzini A, Messina G, Gambini O, et al. Deep-brain stimulation of the nucleus accumbens in obsessive compulsive disorder: clinical, surgical and electrophysiological considerations in two consecutive patients. Neurol Sci 2010;31:353-9. 8

27. Grant JE, Odlaug BL, Chamberlain SR. Long-term deep-brain stimulation treatment for obsessive-compulsive disorder. J Clin Psychiatry 2016;77:132-3.

28. Maarouf M, Neudorfer C, El Majdoub $F$, et al. Deep Brain Stimulation of Medial Dorsal and Ventral Anterior Nucleus of the Thalamus in OCD: A
Retrospective Case Series. PLoS One 2016;11:e0160750.

29. Mallet L, Mesnage V, Houeto JL, et al. Compulsions, Parkinson's disease, and stimulation. Lancet 2002;360:1302-4.

30. Mallet L, Polosan M, Jaafari N, et al. Subthalamic nucleus stimulation in severe obsessive-compulsive disorder. N Engl J Med 2008;359:2121-34.

31. Fontaine D, Mattei V, Borg M, et al. Effect of subthalamic nucleus stimulation on obsessive-compulsive disorder in a patient with Parkinson disease. Case report. J Neurosurg 2004;100:1084-6.

32. Piallat B, Polosan M, Fraix V, et al. Subthalamic neuronal firing in obsessive-compulsive disorder and Parkinson disease. Ann Neurol 2011;69:793-802.

33. Luyten L, Hendrickx S, Raymaekers S, et al. Electrical stimulation in the bed nucleus of the stria terminalis alleviates severe obsessive-compulsive disorder. Mol Psychiatry 2016;21:1272-80.

34. Nuttin B, Gielen F, van Kuyck K, et al. Targeting bed nucleus of the stria terminalis for severe obsessive-compulsive disorder: more unexpected lead placement in obsessive-compulsive disorder than in surgery for movement disorders. World Neurosurg 2013;80:S30 e11-6.

35. Anderson D, Ahmed A. Treatment of patients with intractable obsessivecompulsive disorder with anterior cap- sular stimulation. Case report. J Neurosurg 2003;98:1104-8.

36. Abelson JL, Curtis GC, Sagher O, et al. Deep brain stimulation for refractory obsessive-compulsive disorder. Biol Psychiatry 2005;57:510-6.

37. Chang $\mathrm{CH}$, Chen SY, Hsiao YL, et al. Hypomania with hypersexuality following bilateral anterior limb stimulation in obsessive-compulsive disorder. J Neurosurg 2010;112:1299-300.

38. Nair G, Evans A, Bear RE, et al. The anteromedial GPi as a new target for deep brain stimulation in obsessive compulsive disorder. J Clin Neurosci 2014;21:815-21.

39. Jimenez-Ponce F, Velasco-Campos F, Castro-Farfan G, et al. Preliminary study in patients with obsessive-compulsive disorder treated with electrical stimulation in the inferior thalamic peduncle. Neurosurgery 2009;65:203-9;

40. Jimenez F, Nicolini H, Lozano AM, et al. Electrical stimulation of the inferior thalamic peduncle in the treatment of major depression and obsessive compulsive disorders. World Neurosurg 2013;80:e17-25.

41. Coenen VA, Schlaepfer TE, Goll P, et al. The medial forebrain bundle as a target for deep brain stimulation for obsessive-compulsive disorder. CNS Spectr 2017;22:282-89. 